\title{
CORRELATION OF WELL-BEING WITH RESILIENCE AND AGE
}

\author{
Guna Svence, Maris Majors \\ Riga Teacher Training and Educational Management Academy, Latvia \\ E-mail: guna.svence@rpiva.Iv, maris.majors@rpiva.Iv
}

\begin{abstract}
Resilience and positive thinking, resilience and optimism, kindness as value could be the factors which could impact the future of our humanity and Earth as well as health and welfare of society.

There is an active process of research in the positive psychology carried out in Latvia within the last ten years. The most important category of positive psychology is resilience and well-being. A lot of work has been done regarding adaptation of the concept of well-being and resilience in Latvia. There is a group of young researchers (master level students) who have made a contribution to adaptation of the concept of resilience and well-being in the science of psychology in Latvia at Riga Teacher Training and Education Management Academy (RTTEMA). A group of professors have recently made a joint research, where different samples of adults are demonstrated among the Latvian population in this article. The idea of this research is to analyse the collected secondary data on different groups of adults concerning correlation between the aspects of well-being and resilience.

The aim of the research is to investigate the dimension of well-being in cognitive, eudaimonistic, hedonistic, interpersonal and spiritual (transcendent) relationship with resilience indicators - selfperseverance, self-reliance, acceptance of life, as well as the relevance of well-being indicators to age. One statement of this analysis was the hypothesis about the age as a factor which predetermines development of well-being and resilience.

Methods- 1) Questionnaire on well-being (Majors, Majore, Svence, 2009), 2) Resilience scale, RS (Wagnild, Young, 1993), linguistically adapted by I. Bērzina, G. Svence, 2011), 3) correlation and hierarchical regression analysis of the secondary data.

Questions of the research:

1) what kind of correlation does exist between the indicators of well-being and resilience?

2) which well-being indicators predict these resilience indicators?

3) is there any correlation between the age and well-being?

A data analysis is made in two parts within the framework of this research. Part 1 is dedicated to the examination of the research questions: 1) what kind of correlation does exist between the indicators of well-being and resilience? and 2) which well-being indicators predict these resilience indicators?, people of the Latvian population aged from 16 to 65 years were selected, $28.3 \%$ of men $(N=184$, $M=32.1, S D=11,0$ years), which was made using the secondary data of two studies (Madžule, 2013; Taurina, 2013). Part 2 of the research deals with the examination of the research questions 3 ) is there any correlation between the age and well-being?, people aged from 16 to 65 years were chosen, $24.5 \%$
\end{abstract}



OF PSYCHOLOGY IN THE $21^{\text {st }}$ CENTURY Vol. 9, No. 1, 2015

46 of men $(N=351, M=34.4, S D=11.5)$, which was made using the secondary data of three studies (Majors \& Majore, 2009; Madžule, 2013; Tauriņa, 2013).

It was found out, that the indicators of well-being have a direct and a rather close correlation with the indicators of resilience which provided the answer to the research question, what kind of correlation between the indicators of well-being and resilience exists. The indicators of the well-being dimension indicators have a little or rather close correlation with the parameters of the resilience dimension $(0.29<r<0.58)$. It was found out, that well-being is more predicted by self-reliance of the resilience indicator, which provided the answer to the research question, which well-being indicators predict these resilience indicators. It was found out, that the dimensions of well-being do not correlate with age group in the statistical sense, but only some subdimensions of the purposefulness of well-being in life, perception and transcendence correlate with age at the trend level, providing the answer to the research question, whether there is a correlation between the age and well-being, resilience and age group.

Key words: resilience, resilience indicators-self-reliance, self-perseverance, acceptance of life, well-being, well-being indicators - cognitive, eudaimonistic, hedonistic, interpersonal and spiritual (transcendent), age.

\section{Introduction}

The topicality of the research is related to the adaptation of a new concept of "well-being" and "resilience" in the Latvian sample in a linguistic and psychometric sense. The concept of well-being was adapted at the level of content and in the psychometric sense in cooperation of the two authors of this article in 2007 and 2008 (Svence, Majors, 2009, as mentioned above Svence, 2009). It has been included in the edition of Positive Psychology (Svence, 2009): „...Traditionally, up to now, the concept of well-being was translated from English as a sense of well-being of the subjective life or shortly a sense of well-being or the subjective well-being. The concept of the subjective well-being traditionally includes the idea that represents the optimal experience, optimal self-feeling, life satisfaction and self-evaluation. It was offered to translate the concept of well-being as well-being of life." The substantiation - the research conducted by M. Majors, L. Majore and G. Svence, related to the establishment of the well-being survey in Latvia, as a part of the definition categories and psychometric validity, may be observed in this article.

It is known (as mentioned by Svence, 2009), that the term happiness, and satisfaction with life was used in the 60 -ies of the $20^{\text {th }}$ century, but it was created after as a concept of a subjective sense of well-being in the initial period of positive psychology, but afterwards, when it was found out that people in all cultures do not associate well-being only with pleasure or pleasant feelings, the term psychological well-being was established, which was affected by the studies of C. Ryff (C.Ryff, 1998, as mentioned by Svence, 2009) on the effectiveness of the correlations of a personality's satisfaction with life and autonomy, aims of life and their sense of mastery. This approach was associated with the eudaimonistic approach in the interpretation of well-being. You can find the term "eudaimonistic well-being", which was used in relation to well-being, standing for the idea that people who have high satisfaction concerning the degree of their realization of their autonomy, self-effectiveness, mastery, aims of life, have a high eudaimonistic well-being.

The positive psychologists still consider the general conception of well-being as a sophisticated or complex, i.e., consisting of a number of indicators even after the seven positive European psychology congresses, having published dozens of positive psychology books and hundreds of scientific studies. It is a phenomenon that is controversial due to its subjective nature (point of view from Svence, 2015).

That is why, the long-term research was carried out on the validity of the idea of well-being and its correlation to other positive psychology phenomena and the resilience phenomenon in this article.

Human development is a critical component of the adaptation and resilience that characterizes the ability of people to adapt to crisis situations (Baltes, Carstensen, 1996; Baltes, Staudinger, 
Lindenberger, 1999; Filipp, 1996, as mentioned by Cross S.E., et al, 2003). The personal wellbeing throughout life may be improved by working with personal development factors.

It is proved that resilience helps to resist against distress (Beasley, Thompson, Davidson, 2003; Mathis, Lecci, 1999, as mentioned by Cross, 2003), it may help to functionally adapt to changes or difficulties. You have to understand the mechanisms, how resilience is affected by the changes of personal development and well-being development factors, in order to increase resilience.

As it is shown by several studies (Klohnen, 1996; Werner, Smith, 1992, Klohnen, 1996, Tugade, Frederickson, 2004, Masten, Reed, 2002, Taurina, 2012), there is a close correlation between the well-being and resilience indicators $\left(\mathrm{r}=0,709^{* *}\right.$, as mentioned by Taurina, 2013), a mathematical and statistically significant correlation is found between the common indicator of resilience and eudaimonistic well-being (self-acceptance, positive relations with others, autonomy, the ability to affect the environment and society, purposefulness in life, personal growth and a sense of belonging, authenticity) and general well-being in the age group of early maturity. It has been proved, that the people having high resilience are completely confident about their future, as well as optimistic that they have the ability to affect the environment and the society, have ambitions in life and they completely accept themselves (Klohnen et al., 1996; Tugade, Frederickson, 2004).

It was found that significant correlations are revealed during several studies in Latvia (Taurina, 2012, Bērziña, 2011, Putnina, 2013) between the indicator of resilience and well-being, such as spirituality, transcendence $\left(\mathrm{r}=0,695^{* *}\right.$, as mentioned by Taurina, 2012). The other studies have also shown that people with a high level of resilience have a more energetic approach to life; they are curious and open to new experience (Klohnen, 1996; Tugade, Frederickson, 2004). An average close correlation between resilience and interpersonal well-being $\left(\mathrm{r}=.406^{* *}\right.$, as mentioned by Štāla, 2011, Tauriņa, 2012) in the age group of late maturity is proved, as well. Since the ability of resilience includes optimism, faith, sense of meaning or signification, selfefficacy, the ability to adapt, impulse control, empathy and a sense of positive relations (Masten and Reed, 2002), individuals with a high level of resilience are likely to be more positive towards themselves, as well as they are characterized by a higher indicator of favourableness or agreeableness and consciousness (Walton Viechtbauer, 2006; Brent Lucas, 2008) in the later age group. For example, it has been proved that the overall satisfaction with life increases with age within the adult period (Rocke, 2008). By contrast, other studies showed that satisfaction with life has no connection or is only slightly expressed in relation to the chronological age (Diener et al., 1999; Filipp, 1996; Myers, Diener, 1995). There are contradictions between the results of various researches that led to focus on the issues of the aforementioned research-1) what dimensions of Well-being predict the dimensions of Resilience?, 2) does it have a significantly high level of correlation between the dimensions of Well-being and Resilience, and age as a variable?

\section{Methodology of Research}

\section{General Background of Research}

There is an active process of research in positive psychology carried out in Latvia within the last ten years. There, the most important category of positive psychology is resilience and wellbeing. A great work has been done on the adaptation of the concept of well-being and resilience in Latvia. There is a group of young researchers (master level students), who provided a contribution under supervision of professor Guna Svence to the adaptation of resilience and well-being in the science of psychology in Latvia. There is a joint research recently made by this professor group, where the results of different samples of adults of the Latvian population are demonstrated. The idea of this research is to analyse the collected secondary data on different groups of adults, regarding the correlation between the aspects of well-being and resilience. 
A research sample was established by collecting the secondary data on the work from different studies in Latvia (Riga Teacher Training and Education Management Academy) by (Majors, Majore, \& Svence, 2009, Svence \& Madžule, 2013, Svence \&Tauriņa, 2013) etc. in the first part of this research, in order to examine correlation of the well-being dimension with the resilience dimensions, as well as, which well-being indicators predict these resilience indicators. The data collection was made by consolidating different samples selected before this research, that is why, the data of this research are defined as the secondary data. The primary data were collected before in the form of a survey on the website www.visidati.lv, and by using the snowball sampling method. The data analysis of two samples is included in this article: 1) the Latvian-speaking population of Latvia aged from 16 to 65 years, $28.3 \%$ of men $(\mathrm{N}=184$, $\mathrm{M}=32.1, \mathrm{SD}=11.0$ years), 2) a sample of the Latvian-speaking population aged from 16 to 65 years, $24.5 \%$ of men $(\mathrm{N}=351, \mathrm{M}=34.4, \mathrm{SD}=11.5)$, which was made by using the secondary data.

\section{Tool and Procedures}

A new method for measuring well-being "Well-Being Test (L1)" was established and scientifically justified in the framework of the Bachelor program of Riga Teacher Training and Educational Management Academy (Majors, Majore, 2009), which is also applied in the research described in this article. "Well-Being Test (L1)" is a self-assessment questionnaire, consisting of 68 statements, which are responded according to the Likert-type scale from 0 to 5 . The results provide a possibility to determine the overall well-being indicator, five dimensions and subdimensions of well-being. The Cronbach's alpha coefficient of well-being test dimensions and subdimensions, as well as a number of forming statements, is given in Table 1.

Table 1. Scales of Cronbach's alpha coefficient of well-being test (L1).

\begin{tabular}{lcc}
\hline Subdimensions, Dimensions & Number of statements & $\begin{array}{c}\text { Cronbach's alpha } \\
\text { coefficient }\end{array}$ \\
\hline Happiness & 3 & 0.73 \\
Satisfaction with life & 5 & 0.83 \\
Flow experience & 2 & 0.08 \\
Positive emotions & 5 & 0.80 \\
Hedonic well-being & 15 & 0.89 \\
\hline Self-acceptance & 3 & 0.76 \\
Positive relationships with others & 3 & 0.80 \\
Autonomy & 3 & 0.53 \\
The ability to affect the environment and society & 3 & 0.64 \\
Purposefulness in life & 3 & 0.56 \\
Personal growth & 3 & 0.39 \\
Belonging & 2 & 0.25 \\
Authenticity & 4 & 0.66 \\
Eudaimonistic well-being & 24 & 0.88 \\
\hline Creativity & 2 & 0.74 \\
Sense of the single whole meaning & 4 & 0.59 \\
Optimism & 4 & 0.59 \\
Trust in own abilities & 4 & 0.79 \\
Cognitive well-being & 3 & 0.74 \\
\hline
\end{tabular}




\begin{tabular}{lcc}
\hline Subdimensions, Dimensions & Number of statements & $\begin{array}{c}\text { Cronbach's alpha } \\
\text { coefficient }\end{array}$ \\
\hline Love & 4 & 0.86 \\
Empathy & 2 & 0.63 \\
Selflessness & 2 & 0.50 \\
Values & 2 & 0.10 \\
Interpersonal well-being & 10 & 0.72 \\
\hline Spirituality, transcendence & 5 & 0.78 \\
Well-being & 68 & 0.96 \\
\hline
\end{tabular}

Another tool which was selected is Resilience scale (Resilience scale, RS, Wagnild, Young, 1993) adapted in Latvian by G.Svence, I.Bērziņa, 2011). Resilience scale is a self-assessment tool consisting of 25 statements, where from 1 to 7 respondents assess the statements according to the Likert-type scale. The results of the survey make it possible to determine the total resilience indicator and three subscale indicators: Self-perseverance, Self-reliance, Acceptance of life. The sum of self-perseverance and indicators of self-perseverance constitutes the personal competence indicator, but the indicators of self-perseverance and self-reliance are used separately in this research in order to better investigate the aspects providing correlation. The authors of the Resilience scale point out that the Cronbach's alpha in the original English version is 0.91 (Wagnild \&Young, 1993).

Psychometric evaluation of the Resilience scale is relevant, reliable and valid in the internal sense (Wagnild \& Young, 1993). Despite the fact that the test was originally created to focus on adults, it can be used for teenagers and young adults, as well as in various ethnic groups. The resilience appears as a positive personality trait that characterizes the person's ability to adapt to the challenge situations and "recover" after crisis or tests in Resilience scale easily or in a more difficult way (RS) (Wagnild \& Young 1993).

During the establishment of the concept of resilience adaption in Latvia, the results of approximately 110 articles of meta-analysis were analysed by the authors (Bērzina\&Svence, 2011), and it was found out, that well-being most closely correlates with resilience, and the issue of resilience in the context of different psychological, social and health concepts is very topical in the world.

The test data were processed in accordance with two subscale principles, they are characterized by the following features, but additional analysis was carried out for the research correlation analyzed in this article by taking into account the above-mentioned categorization of five resilience properties - 1) personal competence: self-reliance, independence, determination, mastery and inventiveness categories, and 2) self acceptance and acceptance of life, related to the categories: adaptability, balance, flexibility and a healthy outlook on life which coincides with other definitions of resilience (Wagnild \& Young, 1993).

\section{Data Analysis}

The statistical analysis of data was carried out by means of the correlation analysis and using the factor of Pearson and Hierarchical Regression Analysis of the Dependent Variables.

\section{Results of the Research}

By answering the first research question, what kind of correlation between the indicators of well-being and resilience exists, the results obtained are given in Table 2. 
OF PSYCHOLOGY IN THE $21^{\text {st }}$ CENTURY Vol. 9, No. 1, 2015

Table 2. Pearson correlation coefficients between resilience and its subscales and well-being and its subscales.

\begin{tabular}{|c|c|c|c|c|c|}
\hline & Pearson $r$ & Resilience & Self-perseverance & Self-reliance & $\begin{array}{c}\text { Acceptance } \\
\text { of life }\end{array}$ \\
\hline & Well-being & $0.54^{* *}$ & $0.42^{* *}$ & $0.55^{* *}$ & $0.45^{* *}$ \\
\hline & HHedonic aspect & $0.47^{* *}$ & $0.35^{* *}$ & $0.50^{* *}$ & $0.38^{* *}$ \\
\hline o & Eudaimonistic aspect & $0.58^{* *}$ & $0.47^{* *}$ & $0.56^{* *}$ & $0.46^{* *}$ \\
\hline ON $_{\xi}$ & Cognitive aspect & $0.46^{* *}$ & $0.37^{* *}$ & $0.45^{* *}$ & $0.40^{* *}$ \\
\hline$\underset{\dot{\Phi}}{\Phi}$. & Interpersonal aspect & $0.38^{* *}$ & $0.33^{* *}$ & $0.29^{* \star}$ & $0.35^{* *}$ \\
\hline & Transcendence & $0.48^{* *}$ & $0.35^{* *}$ & $0.51^{* *}$ & $0.41^{* *}$ \\
\hline
\end{tabular}

Note. $N=184 .{ }^{* *} p<0.01$

By analyzing correlations between the indicators of resilience and its subscales (dimensions) and the indicators of well-being and its subscales (dimensions), it is shown that a positive, fairly significant correlation, but statistically significant correlation $\left(\mathrm{r}=0.54^{* *}, \mathrm{p}<0.01\right)$ between the indicators of resilience and well-being is found according to the theoretically expected one, by pointing out that these are different constructions which partially overlap and are interrelated. All the correlations between the indicators of construction subscales are also statistically significant, positive and confirming the mentioned correlation. The correlations between eudaimonistic aspect of well-being and resilience, well-being and self-reliance, eudaimonistic aspect of well-being and self-reliance, self-reliance and the aspect of spirituality and transcendence are moderately strong, the other correlations are assessed as weak.

By analyzing data on correlations of well-being dimensions and resilience dimensions, it was found, that the closest correlation which is significant in the mathematical and statistical sense is between the common indicator of well-being and the common indicator of resilience, as well as the common indicator of well-being and resilience category Self-reliance. The above-mentioned correlation between the indicators of well-being and resilience points out the increase of well-being that leads to the increase of resilience and vice versa.

The regression analysis was conducted in order to answer the second research question and to assess the extent to which the well-being subscale indicators can predict the resilience indicators, the results of which show that by using the indicators of eudaimonistic aspect of well-being and transcendence it is possible to predict $34 \%$ of the resilience indicator. The results obtained are provided in Table 3.

Table 3. Hierarchical regression analysis of the dependent variables, such as resilience, independent variables, such as subscales of well-being ( $\mathbf{N}$ = 184).

\begin{tabular}{ccccc}
\hline & Independent variable & B & SE B & $\beta$ \\
\hline Step 1 & & & & \\
& Eudaimonistic aspect & 14.88 & 1.571 & $0.58^{\star *}$ \\
\hline Step 2 & & & \\
& Eudaimonistic aspect & 11.66 & 2.047 & $0.45^{\star *}$ \\
& Transcendence & 3.67 & 1.521 & $0.19^{*}$ \\
\hline
\end{tabular}

Note. In step $1 R^{2}=0.33, p<0.01$; in step $2 R^{2}=0.34, \Delta R^{2}=0.02, p<0.05$

${ }^{*} p<0.05,{ }^{* *} p<0.01$ 
The regression analysis was conducted in order to assess the extent to which sub-dimensional

indicators included in well-being can predict the indicators of resilience, the results of which show that by using the indicators of well-being sub-dimensions - authenticity, selflessness, belonging, creativity and purposefulness in life, it is possible to predict $45 \%$ of the resilience indicator. The results obtained are provided in Table 4.

Table 4. Hierarchical regression analysis of the dependent variables, such as resilience, independent variables, such as sub-dimensions of wellbeing $(\mathbf{N}=\mathbf{1 8 4})$.

\begin{tabular}{|c|c|c|c|}
\hline Independent variable & B & SE B & $\beta$ \\
\hline \multicolumn{4}{|l|}{ Step 1} \\
\hline Authenticity & 11.16 & 1.14 & $0.59^{* *}$ \\
\hline \multicolumn{4}{|l|}{ Step 2} \\
\hline Authenticity & 10.93 & 1.10 & $0.57^{* *}$ \\
\hline Selflessness & 4.10 & 0.99 & $0.24^{* *}$ \\
\hline \multicolumn{4}{|l|}{ Step 3} \\
\hline Authenticity & 11.95 & 1.13 & $0.63^{* *}$ \\
\hline Selflessness & 4.11 & 0.97 & $0.24^{* *}$ \\
\hline Belonging & -2.84 & 0.98 & $-0.17^{* *}$ \\
\hline \multicolumn{4}{|l|}{ Step 4} \\
\hline Authenticity & 10.93 & 1.17 & $0.58^{* *}$ \\
\hline Selflessness & 3.37 & 0.99 & $0.20^{* *}$ \\
\hline Belonging & -2.95 & 0.97 & $-0.18^{* *}$ \\
\hline Creativity & 2.68 & 0.97 & $0.17^{* *}$ \\
\hline \multicolumn{4}{|l|}{ Step 5} \\
\hline Authenticity & 9.41 & 1.33 & $0.49^{* *}$ \\
\hline Selflessness & 3.02 & 0.99 & $0.18^{* *}$ \\
\hline Belonging & -2.86 & 0.96 & $-0.17^{\star *}$ \\
\hline Creativity & 2.29 & 0.97 & $0.15^{*}$ \\
\hline Purposefulness in life & 2.82 & 1.21 & $0.16^{*}$ \\
\hline
\end{tabular}

The regression analyses to determine the extent to which the indicators of resilience subscales can predict the indicators of well-being showed the lower predictability possibilities. By using the stepwise method of hierarchical regression analysis, it was found that the common indicator of well-being which is significant in the statistical sense can be predicted exactly by the resilience dimension Self-reliance. Self-reliance can predict $30 \%$ of well-being $\left(\mathrm{R}^{2}=30 \%\right.$, $\mathrm{F}(1 ; 182)=77,23, \mathrm{p}<0.01)$.

By applying the aforementioned method, it was found: Self-reliance can predict $25 \%$ of well-being in the hedonic aspect. $\left(\mathrm{R}^{2}=25 \%, \mathrm{~F}(1 ; 182)=60,40, \mathrm{p}<0.01\right)$. Self-reliance and self-perseverance can predict $33 \%$ of well-being in the eudaimonistic aspect. $\left(\mathrm{R}^{2}=33 \%\right.$, $\mathrm{F}(2 ; 181)=45,11, \mathrm{p}<0.01)$. Self-reliance can predict $20 \%$ of well-being in cognitive aspect $\left(\mathrm{R}^{2}=20 \%, \mathrm{~F}(1 ; 182)=45,65, \mathrm{p}<0.01\right)$.

By means of acceptance of life and self-perseverance it is possible to predict $14 \%$ of wellbeing in interpersonal aspect $\left(\mathrm{R}^{2}=14 \%, \mathrm{~F}(2 ; 181)=16.37, \mathrm{p}<0.01\right)$. By means of self-reliance it 
OF PSYCHOLOGY IN THE $21^{\text {st }}$ CENTURY

Vol. 9, No. 1, 2015

52

is possible to predict $26 \%$ of well-being transcendence dimensions $\left(\mathrm{R}^{2}=26 \%, \mathrm{~F}(1 ; 182)=64.96\right.$, $\mathrm{p}<0.01$ ).

By answering the research question, whether there is any correlation between the age and well-being, the results obtained indicate that the correlation is significant in the statistical sense at the trend level of some scales: the age correlates with the scales of well-being: from the scale of Eudaimonistic well-being (category Purposefulness in life), from the scale of Cognitive well-being (category Perception), as well as with the common indicator of Transcendence. It means that Purposefulness in life decreases with the age group, but Perception and Transcendence increase.

It was proved that neither resilience, nor the common indicator, neither scales, nor subcategories correlate with age; it leads to the assumption that age is not the factor in the adult period which affects the ability to experience happiness, hedonic well-being and so on.

Table 5. Pearson correlation coefficients between the well-being dimensions, sub-dimensions and age $(\mathbf{N}=351)$.

\begin{tabular}{|c|c|c|}
\hline & Variables & $r$ \\
\hline 1 & Happiness & 0.07 \\
\hline 2 & Satisfaction with life & $0.19^{* *}$ \\
\hline 3 & Flow experience & -0.68 \\
\hline 4 & Positive emotions & 0.13 \\
\hline 5 & Hedonic aspect & 0.13 \\
\hline 6 & Self-acceptance & $0.20^{* *}$ \\
\hline 7 & Positive relations with others & 0.02 \\
\hline 8 & Autonomy & 0.13 \\
\hline 9 & The ability to affect the environment & -0.03 \\
\hline 10 & Purposefulness in life & $0.24^{* *}$ \\
\hline 11 & Personal growth & -0.03 \\
\hline 12 & Belonging & 0.09 \\
\hline 13 & Authenticity & 0.04 \\
\hline 14 & Eudaimonistic aspect & 0.12 \\
\hline 15 & Creativity & 0.06 \\
\hline 16 & Perception & $0.21^{* *}$ \\
\hline 17 & Optimism & $0.15^{* \star}$ \\
\hline 18 & Trust in own abilities & 0.07 \\
\hline 19 & Cognitive aspect & $0.16^{* *}$ \\
\hline 20 & Love & 0.05 \\
\hline 21 & Empathy & -0.07 \\
\hline 22 & Selflessness & 0.04 \\
\hline 23 & Morality & 0.08 \\
\hline 24 & Interpersonal aspect & 0.05 \\
\hline 25 & Transcendence & $0.22^{* *}$ \\
\hline 26 & Well-being & $0.14^{* *}$ \\
\hline
\end{tabular}

Note. $N=351 .{ }^{*} p<0.05,{ }^{* *} p<0.01$

The possibility at the trend level, age correlates with purposefulness in life (variable number 10 in the table number 5, perception (variable number 16 in the table number 5) and transcendence 
(variable number 25 in the table number 5). Taking into account the substantiation referred to the results in numbers of the named variables, three variables which are closer to the significant level of correlation than others, may be distinguished.

\section{Discussion}

By answering the research question, which resilience indicators are predicted by particular well-being indicators, it was found that well-being is more predicted by the resilience indicator -self-reliance.

By answering the research question, whether there is any correlation between age group and well-being, age group and resilience in the mathematical and statistical sense, it was found that the well-being dimensions do not correlate with the age group in the statistically significant sense, but only purposefulness in life, perception and transcendence correlate with the age group at the trend level.

An interpretation of the connection of self-reliance with the concepts, such as purposefulness in life, self-acceptance, which are substantively similar to well-being was put forward for the discussion, because, as shown by other researches, a mathematically statistically significant correlation is found between the common indicator of resilience and eudaimonistic well-being, including such indicators as self-acceptance, autonomy, purposefulness in life, personal growth, a sense of belonging, authenticity exactly in the early mature age group. It has been proved that people with high resilience are fully confident about their future and are optimistic that they have the ability to affect the environment and the society, ambitions in life and they completely accept themselves (Klohnen et al., 1996; Tugade un Frederickson, 2004, as mentioned by Lielpētere, 2013). Substantively, the phenomenon of self-reliance can be associated with the EU's concept of substantive aspect, such as self-esteem, as well as the well-being indicator "transcendence", including the phenomenon of faith, optimism, hope, sense of humour, gratitude (Seligman, Peterson, 2004, as mentioned by Svence, 2009). Self-reliance is related to the spirituality or transcendence aspect mentioned in other researches, which also supports the result obtained that just self-reliance is the indicator that allows predicting well-being and vice versa. It was also found in several other studies (Tauriņa, 2012, Bērziņa, 2011, Putniņa, 2013). Significant correlations were established between resilience and the indicator of well-being, such as spirituality, transcendence $\left(\mathrm{r}=0.70^{* *}\right.$, as mentioned by Tauriņa, 2012).

The results about the meaning of self-reliance could be interpreted in terms of a sense of spirituality or transcendence - people who have a high self-confidence indicator are more mentally oriented, in crisis situations (challengeable situations) such people show more signs of resilience: faith, optimism, hope, humour, gratitude. There is some interpretation about transcendence in positive psychology- gratitude, hope, humour, playfulness, spirituality, appreciation of beauty and excellence (Boniwell,2006).

This goes hand in hand with the other researches, as the ability of resilience includes optimism, faith, sense of meaning or signification, self-efficacy, the ability to adapt, impulse control, empathy, as well as the sense of positive relations (Masten and Reed, 2002, as mentioned by Bērzina, 2011), the individuals having a high level of resilience are likely to be more positive towards themselves that can be related to the sense of self-reliance.

As regards the issue which was put forward for the discussion related to the relation of age to the well-being and resilience phenomena, it was assumed that such indicators as transcendence, perception increase with the age, because, for example, it has been proved that the overall life satisfaction increases with the age in the adult period (Rocke, 2008, as mentioned by Svence, Majors, 2015). It was assumed that an age group is a significant factor affecting the indicators of resilience and well-being, because, as shown by studies, the age group and environment of human development may be a critical component of the adaptation and resilience, that characterize people's ability to adapt and recover from challenging situations (Baltes, Carstensen, 1996; P. B. Baltes, Staudinger,Lindenberger, 1999; Filipp, 1996, as mentioned by Cross S. E., et al, 
OF PSYCHOLOGY

IN THE $21^{\text {st }}$ CENTURY Vol. 9, No. 1, 2015

2003). Personality development in the interaction with environmental conditions can more or less affect how an individual feels, affect a personal well-being, life satisfaction level throughout life. People with optimal level of resilience are characterized as self-effective, confident and decisive (Wagnild, Young, 1990; Werner, Smith, 199, as mentioned by Brown, et al., 2009). People with these characteristics will more likely express themselves as mostly balanced and will be satisfied with themselves and life in general. Several authors have studied the correlation of well-being and resilience (Klohnen et al., 1996; Tugade, Frederickson, 2004, as mentioned by Cheng, 2004) by demonstrating that as the resilience feature has a multidimensional construction, resilience can correlate with other personality traits or expressions, attitudes and feelings, for instance, well-being, which, in its turn, is related to optimism, overall life satisfaction, achievement motivation and other positive resources of personality.

The results put forward for the discussion are, that age correlates with different indicators of well-being at the trend level - purposefulness in life, perception and transcendence. This is based on the assumption that younger adults (Ryff,1998, as mentioned by Svence,2009) more clearly and often set goals in life by justifying eudaimonistic aspect of well-being. It was assumed according to other similar studies that the older an individual gets, the higher is his level of perception and spirituality - the same openness to experience, extraversion do not change with age, but the trend to cooperate, kindness, conscientiousness grow with age (Wortman, Lucas, Donnellan, 2012, as mentioned by Svence, Majors, 2015). People who choose a deliberate position in difficulties and sufferings, make sense to life; it often happens in the middle of life (Steger, Frazier, Oishi, 2006, as mentioned by Svence, Majors, 2015). It was also supported by our research data that allows further research on the correlation of the indicators of transcendence or spirituality and perception with age.

\section{Conclusions}

It was found that the closest correlation is between the common indicator of well-being and the common indicator of resilience, as well as the common indicator of well-being and resilience category Self-reliance is significant in the mathematical and statistical sense. The results point out that the increase of well-being leads to the increase of resilience and vice versa.

By answering the research question, whether there is correlation between the age and wellbeing, the results obtained indicate that correlation is statistically significant at the trend level of some scales: the age correlates with well-being scales: from the scale Eudaimonistic well-being (category Purposefulness in life), from the scale Cognitive well-being (category Perception), as well as with the common indicator of Transcendence, it means that Purposefulness in life decreases with the age group, but Perception and Transcendence increase.

A regression analysis was conducted in order to assess the extent to which sub-dimensional indicators included in well-being can predict the indicators of resilience, the results of which show that using the indicators of well-being sub-dimensions - authenticity, selflessness, belonging, creativity and purposefulness in life, it is possible to predict $45 \%$ of the resilience indicator. By means of acceptance of life and self-perseverance, it is possible to predict $14 \%$ of well-being in the interpersonal aspect $\left(\mathrm{R}^{2}=14 \%, \mathrm{~F}(2 ; 181)=16.37, \mathrm{p}<0.01\right)$. By means of self-reliance it is possible to predict $26 \%$ of well-being transcendence dimensions $\left(\mathrm{R}^{2}=26 \%, \mathrm{~F}(1 ; 182)=64.96, \mathrm{p}<0.01\right)$.

As regards the results, there are three variables of well-being which are closer to the significant level of correlation than others - purposefulness in life, perception and transcendence. It means that age is a variable that affects understanding of the people purpose of life (more senses of the meaning of purpose of life in early and middle adulthood), perception ( meaningfulness and awareness) and transcendence - gratitude, hope, humour, playfulness, spirituality, appreciation of beauty and excellence. 


\section{References}

Boniwell, I. (2006). Positive psychology in a Nutshell. PWBC, London.

Brown, S. L., Cohn, M. A., Conway, A. M., Fredrickson, B. L., \& Mikels, J. A., (2009). Happiness unpacked: Positive emotions increase life satisfaction by building resilience. Emotion, 9 (3), 361-368.

Cheng, S. T. (2004). Age and subjective well-being revisited: A discrepancy perspective. Psychology and Aging, 19, (3), 409-415.

Cross, S. E., Gore, J. S., \& Morris, M. L. (2003). The relational-interdependent self-construal, self-concept consistency, and well-being. Journal of Personality and Social Psychology, 85, (5), 933-944.

Diener, E. (2000). Subjective well-being: The science of happiness and a proposal for National Index. American Psychologist, 55 (1), 34-43.

Masten, A. S. (2001). Resilience processes in development. American Psychologist, 56, (3), 227-238.

Heather, S. J., Richardson, S. A., Golden-Kreutz, D., M., \& Andersen, B. L. (2006). Strategies used in coping with a cancer diagnosis predict meaning in life for survivors. Health Psychology, 25 (6), 753-761.

Heckhausen, J., \& Lang, F. R. (2001). Perceived control over development and subjective well-being: Differential benefits across adulthood. Irvine Journal of Personality and Social Psychology, 81, (3), 509-523.

Heckhausen, J.,Wrosch, C., \& Schulz, R. (2010). A motivational theory of life-span development. Psychological Review, American Psychological Association, 117, (1), 32- 60.

Lucas, R. E., \& Diener, E. (2001). Understanding extraverts' enjoyment of social situations: The importance of pleasantness. Journal of Personality and Social Psychology, 81 (2), 343-356.

Majors, M., \& Majore, L. (2009). Labizjūtas testa izveide Latvijā. Research study under supervision G.Svence, RTTEMA, Riga (Unpublished).

Madžule, L. (2013). Labizjūtas atšķirības dažādās vecuma grupās. Research study under supervision G.Svence, RTTEMA, Riga. (Unpublished).

Mihailova, O. (2014). Apzinātības, labizjūtas un iekšējās saskaņas izjūtas sieviešu izlasē. Research study under supervision G.Svence, RTTEMA, Riga. (Unpublished).

Pumpuriņa, I. (2011). Vientuḷo māšu dzīvesspēka faktoru izmaiņas pozitīvās intervences grupā. Master theses under supervision G.Svence, RTTEMA, Riga. (Unpublished).

Röcke, Chr., \& Brose, A. (2013). Intraindividual variability and stability of affect and well-being short-term and long-term change and stabilization processes. GeroPsych, 26 (3), 2013, 185-199.

Seligman, M. E. P., \& Csikszentmihalyi, M. (2000). Positive psychology: An introduction. American Psychologist, 55, 5-14.

Seligman, M. E. P., Steen, T. A., Park, N., \& Peterson, C. (2005). Positive psychology progress empirical validation of interventions. American Psychologist, 60 (5), 410-421.

Steger, M. F., Frazier, P., \& Oishi, S. (2006). The meaning in life questionnaire: Assessing the presence of and search for meaning in life. Journal of Counseling Psychology, 53, (1), 80-93.

Svence, G. (2009). Pozit̄̄vā psiholoǵija. Rīga, Zvaigzne ABC.

Svence, G., Majors, M. (2015). Labizjūtas un dzīvesspēka rādītāju saistība ar vecumposma kategoriju Latvijas izlasēs. RPIVA zinātnisko rakstu krājums SIGNUM TEMPORIS (accepted for publishing).

Štāla, E. (2011). Vēlīnā brieduma indivīdu dzīvesspēka un labizjūtas rādītāju izmaiṇas pozitīvās intervences grupā. Master theses under supervision G.Svence, RTTEMA, Riga. (Unpublished).

Tauriṇa, S. (2013). Labizjūtas un dzīvesspēkas sakarības un atšḳirības pieaugušo izlasēs. Research study under supervision G.Svence, RTTEMA, Riga. (Unpublished).

Wagnild, G. M., \& Young, H. M. (1993). Development and psychometric evaluation of the resilience scale. Journal of Nursing Measurement, 1 (2), 165 - 178. 
56 Wortman, J., Lucas, R. E., \& Donnellan, M. B. (2012). Stability and change in the big five personality domains: Evidence from a longitudinal study of Australians. Psychology and Aging, 27 (4), 867-874.

Advised by Laima Railiene, University of Šiauliai, Lithuania

Received: April 26, 2015

Accepted: June 26, 2015

Guna Svence $\quad \mathrm{PhD}$ in Psychology, Professor, Riga Teacher Training and Educational Management Academy, Imantas 7. linija 1, Riga, LV-1083 Latvia.

E-mail: guna.svence@rpiva.Iv

Website: http://www.rpiva.Iv/index.php?mh=izgl_soc_psih

Maris Majors Master in Psychology, Lecturer, Riga Teacher Training and Educational Management Academy (RTTEMA), Imantas 7. linija 1, Riga, LV-1083 Latvia.

E-mail: maris.majors@rpiva.lv 